\title{
Pengelolaan Keuangan Dana Desa (Desa Amahai, Kecamatan Amahai, Maluku Tengah)
}

\author{
Syahrina Noormala Dewi ${ }^{1)}$, Clara Oktavia Lernaya ${ }^{2)}$ \\ 1), 2) Prodi Pendidikan Ekonomi, Universitas Pattimura, Indonesia \\ syahrina.maladewi@gmail.com \\ claraoktavialernaya@gmail.com
}

\begin{abstract}
The purpose of this study was to find out the management of village funds and the implementation of development in the field of empowerment of the Amahai village community, the central district of Amahai Maluku starting form the planning, implementation and administration stages. Data collection is done by observation, interviews and documentation. Data analysis model use reduction, data presentation and conclusion drawing.The results of the study show that the management of village funds in Amahai in the field of community empowerment at the planning, implementation and administration stages has been said to be good even though is has not been effective. This was evidenced by the preparation of the RPJM and RKP on time but out of thirteen community empowerment activities, eleven activities were realized and two activities were not realized.

Key Words : Villages Funds, Empowerment Community
\end{abstract}

\begin{abstract}
Abstrak
Tujuan Penelitian ini adalah untuk mengetahui pengelolaan Dana Desa dan pelaksanaan pembangunan pada bidang pemberdayaan masyarakat di Desa Amahai, Kecamatan Amahai Kabupaten Maluku Tengah dimulai dari tahap perencanaan, pelaksanaan dan penatausahaan. Pendekatan penelitian yang digunakan adalah Deskriptif Kualitatif. Pengumpulan data dilakukan dengan observasi, wawancara dan dokumentasi. Model analisis data menggunakan reduksi data, penyajian data dan penarikan kesimpulan.Hasil penelitian menunjukkan pengelolaan Dana Desa di Desa Amahai dalam bidang pemberdayaan masyarakat pada tahap perencanaan, pelaksanaan dan penatausahaan telah dikatakan baik meski belum efektif. Hal ini dibuktikan dengan penyusunan RPJM dan RKP tepat waktu tetapi dari 13 kegiatan pemberdayaan masyarakat, 11 kegiatan teralisasi dan 2 kegiatan tidak terealisasi.
\end{abstract}

Kata Kunci : Dana Desa, Pemberdayaan Masyarakat

\section{PENDAHULUAN}

Pengelolaan keuangan Desa menurut Permendagri No 133 Tahun 2014 pasal 20,21,22,23dimulai dengan penyusunan perencanaan pembangunan Desa meliputi Rencana Pembangunan Jangka Menengah Desa (RPJM Desa) yang berjangka waktu 6 tahun dan Rencana Kerja Pemerintah Desa (RKP Desa) yang berlaku untuk jangka waktu 1 tahun.Rencana Kerja Pemerintah (RKP) Desa memuat rencana penyelenggaraan pemerintahan Desa, pelaksanaan pembangunan, pembinaan kemasyarakatan, dan pemberdayaan masyarakat Desa dan Rancangan RKP yang telah disepakatilah yang menjadi dasar penyusunan APB Desa. APBDesa merupakan rencana keuangan tahunan pemerintah Desa yang disetujui oleh Badan Permusyawaratan Desa.APB Desa terdiri atas Pendapatan Desa, Belanja Desa, dan Pembiayaan Desa. Pendapatan tersebut antara lain adalah pendapatan Asli desa (PADesa), Alokasi Dana Desa (ADD), Dana Bagi Hasil Pajak dan Retribusi Daerah, Dana Desa (DD), Bantuan Keuangan dari APBD Provinsi; Bantuan keuangan APBD Kabupaten/Kota dan Hibah dan Sumbangan yang tidak mengikat dari pihak ketiga serta pendapatan Lain-lain yang sah. Dana Desa sendiri merupakan wujud dari pemenuhan hak Desa untuk menyelengarakan otonomi Desa agar tumbuh dan berkembang mengikuti pertumbuhan dari Desa itu sendiri berdasarkan keanekaragaman, partisipatif, otonomi asli, demokratisasi dan 
pemberdayaan masyarakat berdasarkan UU No 6 Tahun 2014 Pasal (72) Ayat (1) huruf b dan Ayat (2).

Peraturan Menteri Keuangan (Permenkeu) Republik Indonesia No 49 Tahun 2016 tentang Tata cara pengalokasian, penyaluran, penggunaan, pemantauan dan evaluasi Dana Desa menjelaskan bahwa, Dana desa adalah dana yang bersumber dari APBN yang diperuntukan bagi Desa dan ditransfer melalui APBD Kabupaten/kota setiap tahun untuk membiayai penyelenggaran pemerintahan, pelaksanaan pembangunan, serta pemberdayaan masyarakat, dan pembinaan kemasyarakatan.

Berdasarkan Peraturan Menteri Desa PDTT No 21 Tahun 2016 tentang penetapan prioritas penggunaan Dana Desa, Dana Desa ini diprioritaskan penggunaannya untuk membiayai pelaksanaan program dan kegiatan berskala lokal Desa bidang pembangunan Desa dan pemberdayaan masyarakat Desa. Dalam Peraturan Pemerintah (PP) No 8 Tahun 2016 Pasal 16 disebutkan bahwa Dana Desa Tahun 2016 akan disalurkan secara bertahap oleh pemerintah melalui rekening kas umum negara (RKUN) kepada pemerintah daerah melalui rekening kas umum daerah (RKUD). Kemudian pemerintah daerah kabupaten/kota juga melakukan penyaluran kepada desa melalui rekening kas Desa (RKD) dan berdasarkan besaran alokasi anggaran yang peruntukannya langsung ke Desa ditentukan 10\% (sepuluh perseratus) dari dan di luar dana Transfer Daerah (on top) secara bertahap.

Penelitian yang dilakukan Nyimas latifah (2016) menunjukkan bahwa kendala dalam penyaluran Dana Desa ke Desa dikarenakan masih terdapat penyaluran DD tahap I dari RKUN ke RKUD yang disalurkan melampaui semester I sehingga mempersempit waktu penggunaan/penyerapan di Desa. Selain itu sebagian besar daerah yang lambat penyaluran Dana Desa tahap I disebabkan kesulitan dalam penyusunan laporan realisasi penggunaan-karena laporan ini mengandalkan kepatuhan desa; sebagian besar daerah yang lambat penyaluran Dana Desa tahap I adalah kawasan timur Indonesia; dan masih terdapat penyaluran Dana Desa tahap I dari RKUD ke RKD yang tidak tepat waktu/terlambat dengan sebab: (a) APBDesa belum/terlambat ditetapkan, (b) perubahan regulasi, (c) laporan penggunaan belum dibuat, dan (d) dokumen perencanaan belum ada.

Desa Amahai adalah salah satu Desa yang berada di timur Indonesia, yang memiliki jumlah penduduk $748 \mathrm{KK}$ dengan jumlah jiwa 3958 jiwa dan jumlah keluarga miskin 158 KK dengan luas wilayah 2.545,84 Ha. Desa amahai merupakan salah satu Desa yang menjadi Desa Panutan bagi Desa-desa lainnya di Kecamatan Amahai dan Kebupaten Maluku tengah dalam penyusunan APBDesa dan pengelolaan Dana Desa berdasarkan Permendagri No. 113/2014. Desa Amahai telah melakukan pengelolaan keuangan Desa sesuai dengan regulasi yang telah ditetapkan oleh pemerintah terutama dalam perencanaan Dana Desa yang termuat dalam APBDesa namun dalam pelaksanaan Dana Desanya kendala yang dihadapi adalah keterlambatan penyaluran dana sehingga berdampak bagi penyerapan/penggunaan Dana Desa dalam waktu yang sempit.

Dari fenomena-fenomena diatas maka peneliti ingin meneliti tentang Pengelolaan Dana Desa Pada Desa Amahai Kecamatan Amahai

\section{KAJIAN TEORI DAN PENGEMBANGAN HIPOTESA StewardshipTheory}

Grand theory yang mendasari penelitian ini adalah stewardship theory (DonadsondanJames,1991),yang menggambarkan situasi dimana para manajemen 
organisasi tidaklah termotivasi oleh tujuan- tujuan individu tetapi lebih ditunjukan pada sasaran hasil utama mereka untuk kepentingan organisasi. Dalam stewardship theory manajer atau pejabat desa akan berperilaku sesuai kepentingan bersama (Raharjo,2007).Ketika kepentingan steward dan principals tidak sama, maka steward akan berusaha bekerja sama daripada menentangnya, karena steward merasa kepentingan bersama dan berperilaku sesuai dengan perilaku principals merupakan pertimbangan yang rasional karena steward akan melihat pada usaha dalam mencapai tujuan organisasi.

\section{Desa dan Pemerintahan Desa}

Secara etimologi kata Desa berasal dari bahasa sansekerta, deca yang berarti tanah air, tanah asal, atau tanah kelahiran. Pengertian lainnya Desa adalah suatu hasil perpaduan antara kegiatan sekelompok manusia dengan lingkungannya (bintarto 1983 : 2). Dari sudut pandang geografi, Paul H. Landis berpendapat bahwa Desa adalah suatu wilayah yang penduduknya kurang dari 2.500 jiwa dengan ciriciri antara lainnya memiliki pergaulan hidup yang saling mengenal satu sama lain (adanya rasa kekeluargaan), ada hubungan perasaan yang sama tentang kesukaan terhadap kebiasaan serta cara berusaha bersifat agraris dan sangat dipengaruhi oleh faktor-faktor alam seperti keadaan alam, iklim dan kekayaan alam.

Pengertian resmi tentang Desa menurut undang-undang adalah :

a. UU Nomor 5 tahun 1979

Desa ialah suatu wilayah yang ditempati sejumlah penduduk sebagai kesatuan masyarakat yang di dalamnya merupakan kesatuan hukum yang memiliki organisasi pemerintahan terendah langsung di bawah camat dan berhak menyelenggarakanrumah tangganya sendiri (otonomi) dalam ikatan Negara Kesatuan Republik Indonesia.

b. UU Nomor 22 Tahun 1999

Desa adalah kesatuan masyarakat hukum yang memiliki kewenangan untuk mengatur dan mengurus kepentingan masyarakat setempat berdasarkan asal-usul dan adat istiadat setempat yang diakui dalam sistem pemerintahan Nasional dan berada di daerah kabupaten.

c. UU Nomor 32 Tahun 2004

Desa adalah kesatuan masyarakat hukum yang memiliki batas-batas wilayah yang berwenang untuk mengatur dan mengurus kepentingan masyarakat setempat, berdasarkan asal-usul dan adat istiadat setempat yang diakui dan dihormati dalam sistem pemerintahan pemerintahan Negara Kesatuan Republik Indonesia. Dan selanjutnya dalam PP Nomor 72 Tahun 2005 tentang Desa, bahwa Desa atau yang disebut dengan nama lain, selanjutnya disebut Desa, adalah kesatuan masyarakat hukum yang memiliki batas-batas wilayah yang berwenang untuk mengatur kepentingan masyarakat setempat, berdasarkan asal-usul dan adat istiadat setempat yang diakui dan dihormati dalam sistem Pemerintahan Negara Kesatuan Republik Indonesia.

d. UU Nomor 6 Tahun 2014 Pasal 1

Desa adalah Desa dan Desa adat atau yang disebut denga nama lain, selanjutnya disebut Desa, adalah kesatuan masyarakat hukum yang memiliki batas wilayah yang berwenang untuk mengatur dan mengurus urusan pemerintahan, kepentingan masyarakat setempat berdasarkan prakarsa masyarakat, hak asal usul, dan/atau hak tradisional yang diakui dan dihormati dalam sistem pemerintahan Negara Kesatuan Republik Indonesia. 
Pemerintahan Desa sebagaimana dijelaskan oleh Sendjaja dan Basan (2002:30) merupakan kegiatan dalam rangka menyelenggarakan pemerintahan yang dilaksanakan oleh pemerintah Desa.Menurut Soemantri (2010:7) pemerintahan Desa terdiri dari kepala Desa dan perangkat Desa, sedangkan perangkat Desa terdiri dari sekretaris Desa dan perangkat lainnya, yaitu sekretariat Desa, pelaksanaan teknis lapangan dan unsur kewilayahan, yang jumlahnya disesuaikan dengan kebutuhan dan kondisi sosial budaya setempat.

Pemerintahan Desa berarti terdiri dari Pemerintahan Desa dan Badan Permusyawaratan desa, hal ini telah di atur dalam Pasal 200 Undang-undang Nomor 32 Tahun 2004 yang menyebutkan bahwa, "Dalam Pemerintahan Daerah Kabupaten/Kota dibentuk Pemerintahan Desa yang terdiri dari Pemerintah Desa dan Badan Permusyawaratan Desa”.

Selanjutnya dalam Pasal 202 pada Ayat (1) dan (2) dijelaskan bahwa:

1. Pemerintah Desa terdiri atas Kepala Desa dan Perangkat Desa;

2. Perangkat Desa terdiri dari Sekretaris Desa dan Perangkat Desa lainnya.

Dalam UU No 6 Tahun 2014 Desa atau yang disebut dengan nama lain mempunyai karakteristik yang berlaku umum untuk seluruh Indonesia, sedangkan Desa Adat atau yang disebut dengan nama lain mempunyai karakteristik yang berbeda dari Desa pada umumnya, terutama karena kuatnya pengaruh adat terhadap sistem pemerintahan lokal, pengelolaan sumber daya lokal, dan kehidupan sosial budaya masyarakat Desa.

Desa Adat memiliki hak asal usul yang lebih dominan daripada hak asal usul Desa sejak Desa Adat itu lahir sebagai komunitas asli yang ada di tengah masyarakat.Dalam kaitan itu, negara mengakui dan menghormati kesatuan masyarakat hukum adat beserta hak tradisionalnya sepanjang masih hidup dan sesuai dengan perkembangan masyarakat dan prinsip Negara Kesatuan Republik Indonesia.

Implementasi dari kesatuan masyarakat hukum adat tersebut telah ada dan hidup di wilayah Negara Kesatuan Republik Indonesia, seperti huta/nagori di Sumatera Utara, gampong di Aceh, nagari di Minangkabau, marga di Sumatera bagian selatan, tiuh atau pekon di Lampung, desapakraman/desa adat di Bali, lembang di Toraja, banua dan wanua di Kalimantan, dan negeri di Maluku. Maka kelembagaan Desa/Desa Adat, yaitu lembaga Pemerintahan Desa/Desa Adat yang terdiri atas Pemerintah Desa/Desa Adat dan Badan Permusyawaratan Desa/Desa Adat, Lembaga Kemasyarakatan Desa, dan lembaga adat.

Dari beberapa definisi yang telah diuraikan tentang pemerintahan Desa dapat disimpulkan bahwa Kepala Desa dan Badan Permusyawaratan Desa yang dipercaya oleh masyarakat bertugas menyelenggarakan pemerintahan dan mereka juga mengatur dan mengurus segala sesuatu kepentingan masyarakat setempat berdasarkan asal usul dan adat istiadat.

\section{Peran pemerintah desa dalam mengelola Pembangunan Desa}

Pembangunan Desa merupakan seluruh kegiatan pembangunan yang berlangsung dipedesaan, meliputi seluruh aspek kehidupan dari seluruh masyarakat yang dilaksanakan secara terpadu dengan mengembangkan swadaya gotong royong. Indikator keberhasilan pembangunan Desa pada dasarnya adalah perbaikan rill dalam kondisi kehidupan masyarakat secara keseluruhan, karena pembangunan senantiasa merupakan proses perbaikan dari suatu keadaan ke keadaan yang lebih baik. Suparno (2001:46) menegaskan bahwa pembangunan Desa dilakukan dalam rangka imbang yang sewajarnya antara pemerintah dengan masyarakat.Kewajiban 
pemerintah adalah menyediakan prasarana-prasarana sedangkan selebihnya disandarkan kepada kemampuan masyarakat itu sendiri.Ahmadi (2001:222) menjelaskan mekanisme pembangunan Desa adalah merupakan perpaduan yang serasi antara kegiatan partisipasi masyarakat dalam pihak dan kegiatan pemerintah di satu pihak.UU Nomor 6 Tahun 2014 pasal 1 ayat (8) menyatakan bahwa pembangunan Desa adalah meningkatkan kesejahteraan masyarakat Desa dan kualitas hidup manusia serta penanggulangan kemiskinan melalui pemenuhan kebutuhan dasar, pembangunan sarana dan prasarana Desa, pengembangan potensi ekonomi lokal, serta pemanfaatan sumber daya alam dan lingkungan secara berkelanjutan.

Menurut Peraturan Menteri Dalam Negeri Republik Indonesia Nomor 114 Tahun 2014 Pembangunan Desa adalah upaya peningkatan kualitas hidup dan kehidupan untuk sebesar-besarnya kesejahteraan masyarakat Desa. Perencanaan pembangunan Desa adalah proses tahapan kegiatan yang diselenggarakan oleh Pemerintah Desa dengan melibatkan Badan Permusyawaratan Desa dan unsur masyarakat secara partisipatif guna pemanfaatan dan pengalokasian sumber daya Desa dalam rangka mencapai tujuan pembangunan Desa.Pembangunan Desa pada hakekatnya dilakukan oleh masyarakat sendiri, sedangkan pemerintah memberikan bimbingan, bantuan, pembinaan dan pengawasan dengan tujuan meningkatkan kesejahteraan masyarakat Desa dan kualitas hidup manusia. Kepala Desa sebagai pemerintah Desa bertanggung jawab dalam menyelenggarakan pemerintahan Desa, melaksanakan pembangunan Desa, pembinaan kemasyarakatan Desa dan pemberdayaan masyarakat.

Dalam penyelengaraannya kegiatan pembangunan lebih terperinci (berupa usulan kegiatan) menjadi kewenangan masyarakat Desa dalam mengambil keputusan melalui Musdes dan Musrembangdes.Hasil Musdes dan Musrembangdes berupa RPJM desa dan RKP selanjutnya dituangkan dalam dokumen APB Desa sebagai dokumen pelaksanaan anggaran di Desa. Berdasarkan Permendagri Nomor 114 Tahun 2014 tentang Pedoman Pembangunan Desa, ketentuan Pasal 6 bahwa ruang lingkup perencanaan pembangunan Desa memuat visi danmisi kepala desa, arah kebijakan pembangunan Desa, serta rencana kegiatan yang meliputibidang penyelenggaraan pemerintahan Desa, pelaksanaan pembangunan, pembinaankemasyarakatan, dan pemberdayaan masyarakat Desa.

\section{Konsep dan Defensi Dana Desa (DD) Dana Desa (DD) dan tujuan Pengelolaanya}

Dalam UU Nomor 6 Tahun 2014 Dana Desa adalah anggaran yang bersumber dari Anggaran Pendapatan dan Belanja Negara yang diperuntukan bagi Desa dan Desa Adat yang ditransfer melalui anggaran pendapatan dan belanja daerah kabupaten/kota yang digunakan untuk membiayai penyelenggaraan pemerintah, pembangunan, serta pemberdayaan masyarakat dan kemasyarakatan.

Anggaran yang bersumber dari APBN dihitung berdasarkan jumlah Desa dan dialokasikan dengan memperhatikan jumlah penduduk, angka kemiskinan, luas wilayah, dan tingkat kesulitan geografis dalam rangka meningkatkan kesejahteraan dan pemerataan pembangunan Desa (Deputi Bidang Pengawasan Penyelenggaraan Keuangan Daerah, 2015).

Adapun yang menjadi persyaratan penyaluran DD berdasarkan Peraturan Menteri Keuangan No.49/PMK.07/2016 bahwa DD dapat disalurkan dari RKUN ke RKUD setelah persyaratan dipenuhi. Kemudian paling lambat 7 (tujuh) hari kerja setelah diterima di RKUD barulah disalurkan ke RKD. Apabila 
Bupati/Walikota tidak menyalurkan sebagaimana yang dimaksud akan dikenakan sanksi administratif berupa penundaan penyaluran DAU (Dana Alokasi Umum) dan/atau DBH (Dana Bagi Hasil) yang menjadi hak kabupaten/kota bersangkutan.

Persyaratan penyaluran DD pada tahap I bahwa penyaluran dari RKUN ke RKUD haruslah dilengkapi dengan dokumen (a) Perda mengenai APBD Kabupaten/Kota tahun berjalan; (b) Perbup/Walikota Mengenai Tata Cara Pembagian dan Penetapan besaran DD; (c) Laporan Realisasi Penyaluran Dan Konsolidasi Penggunaan DD Tahap Sebelumnya. Kemudian Penyaluran DD dari RKUD Ke RKD haruslah dilengkapi dengan dokumen (a) Perdes mengenai APB Desa tahun anggaran berjalan dan (b) Laporan realisasi penggunaan DD tahap sebelumnya. Apabila dokumen tersebut belum/terlambat disampaikan, Menteri atau Bupati/Walikota mengenakan sanksi administratif berupa penundaan penyaluran DD sampai dipenuhinya dokumen tersebut.Dalam hal ini, penundaan terjadi karena sebagian daerah belum memasukkan DD ke dalam APBD induk, dan terlambat menetapkan perbup/perwali tentang pengalokasian DD per desa.

Untuk penyaluran tahap II bahwa penyaluran DD dari RKUN ke RKUD dilakukan setelah Menteri cq. Dirjen Perimbangan Keuangan menerima laporan realisasi penyaluran dan penggunaan DD tahap I dari Bupati/Walikota, dan laporan realisasi penyaluran dan konsolidasi penggunaan DD tahap I menunjukkan paling kurang 50\% (lima puluh persen). Kemudian penyaluran DD dari RKUD ke RKD dilakukan setelah Bupati/Walikota menerima laporan realisasi penggunaan DD tahap I dari Kades (kepala Desa) dan laporan realisasi tahap I menunjukkan paling kurang 50\%. (Nyimash latifah,2016)

\section{Pengelolaan Dana Desa}

Menurut Thomas (2013) pengelolaan adalah suatu proses atau suatu rangkaian pekerjaan yang dilakukan oleh serangkaian kelompok orang di dalamnya terdapat perencanaan, pengorganisasian, pelaksanaan dan pengawasan dengan memanfaatkan potensi yang ada dalam mencapai tujuan tertentu.Pengelolaan DD dalam Peraturan Presiden No 60 Tentang Dana Desa Pasal 2 berbunyi Dana Desa dikelola secara tertib, taat pada ketentuan peraturan perundang-undangan, efisien, ekonomis, transparan, dan bertanggung jawab dengan memperhatikan rasa keadilan dan kepatutan serta mengutamakan kepentingan masyarakat setempat. Adapun dalam Peraturan Menteri Keuangan Nomor 49 tentang Tata Cara Pengalokasian, Penyaluran, Penggunaan, Pemantauan dan Evaluasi Dana Desa Pasal 22 Ayat 2 berbunyi pelaksanaan kegiatan yang dibiayai dari Dana Desa diutamakan dilakukan secara swakelola dengan menggunakan sumberdaya/bahan baku lokal, dan diupayakan dengan lebih banyak menyerap tenaga kerja dari masyarakat Desa setempat. Adapun keseluruhan kegiatan dalam pengelolaan keuangan Desa berdasarkan peraturan pemerintah dalam Permendagri No. 113/2014 tentang Pengelolaan keuangan Desa antara lain :

a. Perencanaan

Perencanaan yang di maksudkan mengenai penyusunan APBDesa berdasarkan RKP Desa dan penggunaan prioritas Dana Desa ditetapkan dalam musyawarah Desa antara BPD, Pemdes dan Masyarakat.

b. PelaksanaaN

Dalam pelaksanaannya Dana Desa ditransfer melalui APBD kabupaten/kota untuk selanjutnya ditransfer ke APB Desa. Penyaluran Dana Desa dilakukan secara bertahap dengan cara pemindahbukuan dari RKUN ke RKUD, selanjutnya dari kabupaten/kota disalurkan ke Desa dilakukan dengan cara 
pemindahbukuan dari RKUD ke Rekening KasDesa. Dan semua penerimaan dan pengeluaran Desa sebagaimana dimaksud harus didukung oleh bukti yang lengkap dan sah.

c. Penatausahaan

Penatausahaan dilakukan oleh bendahara Desa, sebagaimana dimaksud dalam Pasal 35 Ayat (2),Penatausahaan penerimaan dan pengeluaran menggunakan: a. buku kas umum; b. buku kas pembantu pajak; dan c. buku bank.

d. Pelaporan

Dalam melaksanakan tugas, kewenangan, hak, dan kewajibannya dalam pengelolaan keuangan Desa, kepala Desa memiliki kewajiban untuk menyampaikan laporan. Laporan tersebut bersifat periodik semesteran dan tahunan diantaranya adalah Penyampaian laporan realisasi penggunaan Dana Desa dilakukan:

- Untuk semester I paling lambat minggu keempat bulan Juli tahun anggaran berjalan.

- Untuk semester II paling lambat minggu keempat bulan Januari tahun anggaran berikutnya.

e. Pertanggung jawaban

Dalam pertanggungjawabannya kepala Desa menyampaikan Laporan pertanggungjawaban Realisasi Pelaksanaan ABPDesa termasuk didalamnya pendapatan, belanja dan transfer yang berasal dari Dana Desa kepada Bupati/Walikota setiap akhir tahun anggaran.

\section{METODE PENELITIAN}

Jenis penelitian yang digunakan adalah kualitatif, dengan pendekatan yang digunakan adalah pendekatan deskriptif. Jenis data yang digunakan dalam penelitian ini adalah data primer dan data sekunder. Metode pengumpulan data yang digunakaan dalam penelitian ini adalah wawancara mendalam, studi pustaka, dan studi dokumentasi. Penelitian ini dilakukan dengan melakukan survei, observasi, hingga kajian kepustakaan untuk menjawab pertanyaan penelitia. Adapun alat-alat penelitian yang digunakan peneliti dalam melakukan penelitian, yaitu perekam suara, buku catatan, handphone, kamera, alat tulis, daftar pertanyaan wawancara, dan buku, jurnal, dan referensilainnya. Salim (2006) proses analisis data dilakukan sejak pengumpulan data sampai selesainya proses pengumpulan data tersebut. Adapun proses-proses tersebut dapat dijelaskan kedalam tiga tahap, yaitu reduksi data, penyajian data,dan penarikankesimpulan.

\section{HASIL DAN PEMBAHASAN}

Dengan mengacu pada Permendagri No 133 Tahun 2014 maka Negeri Amahai selanjutnya disebut Desa Amahai juga turut melaksanakan pengelolaan keuangan Desa dengan baik sehingga dinyatakan sebagai salah satu Desa panutan pengelolaan keuangan Desa bagi Desa lainnya di Kecamatan Amahai.

\subsection{Tahapan-Tahapan Pengelolaan Keuangan Desa}

Tahapan-tahapan pengelolaan keuangan Desa pada Desa Amahai tersebut dapat dijelaskan antara lain sebagai berikut :

\section{Perencanaan}

Permendagri No 133 Tahun 2014 Pasal 20, 21, 22 dan 23 dalam penerapannya di Desa Amahai dimulai dari penyusunan perencanaan pembangunan 
Desa meliputi RPJM Desa dan RKP Desa yang disusun secara berjangka dan ditetapkan dengan Peraturan Desa. Rencana Pembangunan Jangka Menengah Desa (RPJM Desa) untuk jangka waktu 6 (enam) tahun sedangkan Rencana Pembangunan Tahunan Desa atau yang disebut Rencana Kerja Pemerintah Desa (RKP Desa) untuk jangka waktu 1 (satu) tahun.

RKP Desa Amahai merupakan penjabaran dari Rencana Pembangunan Jangka Menengah Desa Amahai. Dalam menyusun RPJM Desa, pemerintah Desa Amahai wajib menyelenggarakan Musyawarah Perencanaan Pembangunan Desa (Musrenbangdes) secara partisipatif. Musrenbang desa diikuti oleh pemerintah Desa/Negeri Amahai, Badan Saniri Negeri Amahai dan unsur masyarakat Negeri Amahai, yang terdiri atas tokoh adat, tokoh agama, tokoh masyarakat dan/atau tokoh pendidikan. Hasil dari musrembangdes berupa RPJM inilah yang kemudian dijabarkan lagi dalam RKP Desa (rancangan kerja pemerintah Desa) sebagai rancangan pembangunan tahunan.

Dalam proses persiapan penyusunan RKP bahannya disiapkan terlebih dahulu oleh sekretaris Desa dan dibantu oleh kaur perencanaan dan paling sedikit terurai didalamnya antara lain :

1. Evaluasi pelaksanaan RKP Desa tahun sebelumnya;

2. Prioritas program, kegiatan, dan anggaran Desa yang dikelola oleh Desa;

3. Prioritas program, kegiatan, dan anggaran Desa yang dikelola melalui kerja sama antar-Desa dan pihak ketiga;

4. Rencana program, kegiatan, dan anggaran Desa yang dikelola oleh Desa sebagai kewenangan penugasan dari pemerintah, pemerintah daerah provinsi, dan pemerintah daerah kabupaten/kota;

5. Pelaksana kegiatan Desa, yang terdiri atas unsur perangkat Desa dan/atau unsur masyarakat Desa.

Setelah itu penyusunan RKP Desa yang dilaksanakan oleh Tim RKP. Adapun kegiatan dan program yang telah dirancang didalam RKP terkhususnya kegiatan yang sumber pembiayaannya berasal dari Dana Desa maka kegiatan dan program yang direncanakan haruslah berdasarkan prioritas Dana Desa yang mengacu pada Peraturan Menteri Desa Tertinggal Dan Transmigrasi Nomor 5 TentangPenetapan Prioritas Penggunaan Dana Desa Tahun 2015. Mekanisme selanjutnya setelah penyusunan RKP kemudian RKP sebagai rancangan peraturan Desa tentang APBDesa sebagaimana dimaksud pada ayat (2) dalam permendagri 133 tahun 2014 disampaikan oleh Kepala Pemerintahan Negeri Amahai kepada Badan permusyawaratan Desa (badan saniri negeri) untuk dibahas selanjutnya disepakati bersama menjadi peraturan Desa tentang RKP Desa Amahai. Setelah RKP Desa ditetapkan maka dilanjutkan proses penyusunan APB Desa dengan menggunakan rencana kegiatan dan rencana anggaran biaya yang telah ditetapkan dalam RKP Desa sebagai pedoman dalam proses penganggarannya. Berikut ini disajikan Tabel Anggaran Pendapatan Dan Belanja Negeri Amahai (APBNeg Amahai) tahun 2017

Tabel 4.7 Anggaran Pendapatan Dan Belanja Negeri Pemerintahan Negeri Amahai Tahun Anggaran 2017 
INVENTORY : Jurnal Akuntansi Vol. 4 No. 1 April 2020

\begin{tabular}{|c|c|c|c|c|c|c|}
\hline \multicolumn{3}{|c|}{$\begin{array}{c}\text { Kode } \\
\text { rek }\end{array}$} & Uraian & & Anggaran & Ket \\
\hline \multicolumn{3}{|c|}{1} & Pendapatan & & & \\
\hline 1 & 1 & & Pendapatan Asli Negeri & $\mathrm{Rp}$ & $92,000,000.00$ & \\
\hline 1 & 2 & & Pendapatan Transfer & $\mathrm{Rp}$ & $1,405,511,011.00$ & \\
\hline 1 & 2 & 1 & Dana Desa & $\mathrm{Rp}$ & $832,083,538.00$ & \\
\hline 1 & 2 & 2 & $\begin{array}{l}\text { Bagian Dari Hasil Pajak \&Retribusi } \\
\text { Daerah Kabupaten/Kota }\end{array}$ & & - & \\
\hline 1 & 2 & 3 & Alokasi Dana Desa & $\mathrm{Rp}$ & $573,427,473.00$ & \\
\hline 1 & 2 & 4 & Bantuan Keuangan & & - & \\
\hline \multirow[t]{2}{*}{1} & 3 & & Pendapatan Lain-Lain & $\mathrm{Rp}$ & $8,000,000.00$ & \\
\hline & & & Jumlah Pendapatan & $\mathrm{Rp}$ & $1,505,511,011.00$ & \\
\hline \multicolumn{3}{|c|}{2} & Belanja & & & \\
\hline 2 & 1 & & $\begin{array}{l}\text { Bidang Penyelenggaraan Pemerintahan } \\
\text { Negeri }\end{array}$ & $\mathrm{Rp}$ & $342,585,948.00$ & $\mathrm{ADD} / \mathrm{PAN}$ \\
\hline 2 & 2 & & Bidang Pelaksanaan Pembangunan Negeri & $\mathrm{Rp}$ & $701,668,709.00$ & $\mathrm{ADD} / \mathrm{DD}$ \\
\hline 2 & 3 & & Bidang Pembinaan Masyarakat & $\mathrm{Rp}$ & $106,064,000.00$ & ADD/PAN \\
\hline 2 & 4 & & Bidang Pemberdayaan Masyarakat & $\mathrm{Rp}$ & $317,731,000.00$ & DD \\
\hline \multirow[t]{2}{*}{2} & 5 & & Biaya Tak Terduga & & & \\
\hline & & & Jumlah Belanja & $\mathrm{Rp}$ & $1,468,049,657.00$ & \\
\hline \multicolumn{3}{|c|}{3} & Pembiayaan & & & \\
\hline 3 & 1 & & Penerimaan Pembiayaan & & - & \\
\hline 3 & 1 & 1 & SILPA Tahun lalu (2015) & $\mathrm{Rp}$ & $42,538,646.00$ & PAN/DD \\
\hline 3 & 1 & 2 & Pencairan dana cadangan & & - & \\
\hline \multirow[t]{2}{*}{3} & 1 & 3 & Hasil kekayaan desa yang dipisahkan & & & \\
\hline & & & $\begin{array}{l}\text { Jumlah } \\
\end{array}$ & $\mathrm{Rp}$ & $42,538,646.00$ & PAN/DD \\
\hline 3 & 2 & & Pengeluaran pembiayaan & & - & \\
\hline 3 & 2 & 1 & Pembentukan dana cadangan & & - & \\
\hline \multirow[t]{2}{*}{3} & 2 & 2 & Penyertaan modal desa BUMNeg & $\mathrm{Rp}$ & $80,000,000.00$ & DD \\
\hline & & & Jumlah & $\mathrm{Rp}$ & $80,000,000.00$ & DD \\
\hline
\end{tabular}

Sumber : diolah dari data sekunder (APBNeg Amahai tahun 2016)

Berdasarkan tabel 4.7 diatas dapat dilihat bahwa Negeri Amahai setiap tahunnya mengalami peningkatan pendapatan baik dari pendapatan asli negeri, pendapatan transfer maupun pendapatan lain-lain. Pendapatan Asli negeri yang diperoleh Negeri Amahai secara rinci adalah berasal dari hasil BUMneg dan Tanah kas negeri kemudian ada juga hasil aset negeri diantaranya itu adalah hasil sewa balai negeri, penginapan negeri, tambatan perahu dan kunjungan objek wisata mangrove yang merupakan salah satu tempat wisata milik Negeri Amahai selain itu juga terdapat swadaya masyarakat dan pendapatan lainnya yang sah seperti hasil kompensasi dari jual beli tanah yang dilakukan oleh masyarakat desa amahai, pembuatan surat keterangan tanah maupun harta kawin anak gadis mengingat Pendapatan Asli Negeri ini tidak selalu tetap sehingga pada setiap tahunnya dapat mengalami peningkatan maupun penurunan. 
Namun dengan adanya Pendapatan Asli Negeri maka sangat membantu pemerintah desa amahai dalam melaksanakan belanja bidang penyelenggaraan pemerintahan negeri yang didalamnya secara umum adalah untuk membayar penghasilan dan tunjangan kepala pemerintah Negeri Amahai dan perangkat Negeri Amahai serta insentif bagi perangkat dusun dan juga operasional perkantoran. Selanjutnya pendapatan transfer yang diperoleh Negeri Amahai seperti yang dilihat pada Tabel 4.7 antara lain salah satunya adalah Dana Desa berdasarkan Peraturan Menteri Desa, Pembangunan Daerah Tertinggal, dan Transmigrasi Nomor 21 Tahun 2015 disebutkan bahwa prioritas penggunaan Dana Desa Tahun 2016 adalah untuk bidang Pembangunan Desa dan Bidang Pemberdayaan Masyarakat Desasehingga pada tahun 2017 Dana Desa pada Negeri Amahai yang berjumlah sebesar Rp 832,083,538.00. Secara keseluruhan digunakan untuk membiayai kegiatan dan program dalam bidang pelaksanaan pembangunan Desa dan bidang pemberdayaan masyarakat Desa sesuai dengan Rancangan Kerja Pemerintah Desa selama 1 tahun yang telah termuat dalam APBdes. Dalam penelitian ini peneliti berfokus pada bidang pemberdayaan masyarakat tahun anggaran 2017 mengingat Peraturan Menteri Desa, Pembangunan Daerah Tertinggal, dan Transmigrasi terkait prioritas Dana Desa dan Desa Amahai dalam bidang pemberdayaannya baru saja berkembang pesat dan hasilnya dapat dirasakan langsung oleh para pengguna manfaat setelah Dana Desa dikucurkan yang dimulai pada tahun anggaran 2015 sampai sekarang ini.

\section{Pelaksanaan}

Dalam pelaksanaan pengelolaan Dana Desa pada Desa Amahai agar dalam pengelolaannya lebih terarah sehingga kegiatan dan program yang telah dirancang dapat terealisasi secara tepat waktu dan tepat sasaran bagi para pengguna manfaat Dana Desa maka Kepala Pemerintahan Desa Amahai menetapkan SK pembentukan Tim Pelaksana Kegiatan (TPK) yang dalam tugas dan fungsinya berperan untuk melakukan pelaksanaan dan penatausahaan pengelolaan Dana Desa pada tahun yang didanai. Pembentukan TPK ini berlangsung saat dana akan direalisasikan oleh karenanya TPK tidak terlibat dalam proses penetapan prioritas kegiatan dan program yang didanai oleh Dana Desa. Selanjutnya setelah Dana Desa dicairkan maka merujuk pada Permendagri No 113 Tahun 2014 Pasal 27 bahwa pelaksana kegiatan (PTPKD termasuk didalamnya TPK) yang akan mengajukan pendanaan untuk melaksanakan kegiatan harus disertai dengan Rencana Anggaran Biaya (RAB) yang kemudian diverifikasi oleh sekretaris Desa dan disahkan oleh Kepala Desa kemudian pelaksana kegiatan juga harus mencatat beban anggaran belanja kegiatan tersebut didalam buku pembantu kas. Berikut kegiatan dan program bidang pemberdayaan masyarakat yang termuat dalam APBDesa Amahai tahun 2017 : Penyediaan Makan Tambahan Bagi Bayi Dan Balita

Tabel 4.9. Rincian Perhitungan Anggaran Program Penyediaan Makan Tambahan Bagi Bayi dan Balita

\begin{tabular}{|c|c|c|c|c|c|}
\hline \multirow[b]{2}{*}{ No } & \multirow[b]{2}{*}{ Uraian } & \multicolumn{3}{|c|}{ Rincian Perhitungan } & Jumlah \\
\hline & & Volume & Satuan & Harga & $\mathrm{Rp}$ \\
\hline 1 & 2 & 3 & 4 & 5 & $6=(3 * 5)$ \\
\hline 1 & Belanja barang dan jasa & & & & $\mathrm{Rp} \quad 19,440,000.00$ \\
\hline & $\begin{array}{l}\text { Bantuan Untuk PMT Balita dan } \\
\text { Bayi }\end{array}$ & & & & \\
\hline & * 5 Posyandu x 12 bulan & 60 & bln & Rp $324,000.00$ & Rp $19,440,000.00$ \\
\hline
\end{tabular}


Tabel 4.9 menunjukkan perincian anggaran program penyediaan makan tambahan bagi bayi dan balita dengan penjelasan yaitu ada 5 pos pelayanan terpadu yang menyediakan Makanan tambahan satu bulan sekali pada saat penyelenggaraan posyandu yaitu pada minggu ke 3 bulan berjalan dengan anggaran Penyediaan makanan tambahan sebesar Rp 324,000.00,- per bulan sehingga dalam jangka waktu 1 tahun (12 bulan) anggaran PMT yang didanai oleh dana desa melalui bidang pemberdayaan masyarakat total berjumlah Rp 19.440.400.00,- . Dalam kegiatan ini Pemerintah Negeri Amahai terkhususnya Tim pengelola kegiatan bekerja sama dengan kader posyandu, sejumlah uang yang Tim pengelola kegiatan cairkan dari bendahara berdasarkan SPP (Surat Permintaan Pembayaran) untuk program bantuan penyediaan makanan tambahan balita dan bayi diserahkan kepada kader posyandu untuk nantinya digunakan untuk penyediaan penyediaan makanan tambahan pada anak dan bayi setiap minggu ketiga pada bulan berjalan.

\section{Penanganan Layanan Kesehatan Masyarakat Miskin (Balita dan Balita Kurang Gizi)}

Tabel 4.10 Rincian Perhitungan Anggaran Program Penanganan Layanan Kesehatan Masyarakat Miskin (Bayi dan Balita Kurang Gizi)

Tabel 4.10 menunjukkan perincian anggaran penanganan anak dan balita kurang gizi adalah ada 10 anak dari 5 posyandu yang mengalami kurang Gizi (stunting) dan Pemerintah Negeri Amahai membantu menangani bayi dan balita

\begin{tabular}{|c|c|c|c|c|c|c|c|}
\hline \multirow{2}{*}{ No } & \multirow[b]{2}{*}{ Uraian } & \multicolumn{4}{|c|}{ Rincian Perhitungan } & \multirow{2}{*}{\multicolumn{2}{|c|}{$\frac{\text { Jumlah }}{\mathrm{Rp}}$}} \\
\hline & & Volume & Satuan & & arga Satuan & & \\
\hline 1 & 2 & 3 & 4 & & 5 & & $6=(3 * 5)$ \\
\hline 1 & Belanja Barang Dan Jasa & & & & & $\mathrm{Rp}$ & $16,440,000.00$ \\
\hline & $\begin{array}{l}\text { Penanganan Anak Dan } \\
\text { Balita Kurang Gizi }\end{array}$ & & & & & & \\
\hline & $\begin{array}{l}* 5 \text { posyandu } \times 2 \text { anak x } 5 \times \\
12 \text { bulan }\end{array}$ & 60 & $\mathrm{~B} \ln$ & $\mathrm{Rp}$ & 27.400 .00 & $\mathrm{Rp}$ & $16,440,000.00$ \\
\hline \multicolumn{6}{|c|}{ Jumlah } & $\mathrm{Rp}$ & $16,440,000.00$ \\
\hline
\end{tabular}

yang mengalami gizi buruk ini dengan memberikan makanan tambahan sebanyak 5 kali setiap bulan selama 1 tahun anggaran 2017 yang dalam perinciannya adalah 10 anak (2 anak dari 5 posyandu) x 5 kali makanan tambahan x 12 bulan x Rp. 27.400 (harga makanan per anak) $=$ Rp. 16.440.000.00

Penjelasan ini menyatakan bahwa berdasarkan pemantauan orang tua dari bayi penerima manfaat dan kader posyandu pada tahun anggaran tersebut adanya peningkatan perkembangan kesehatan bagi anak-anak gizi kurang dimana dari status gizi kurang berangsur-angsur membaik. Ini membuktikan bahwa Program ini dapat direalisasikan dengan baik

Layanan Kesehatan Susu Untuk Ibu Hamil Kekurangan Energi Kronik

Tabel 4.11 Rincian Perhitungan Anggaran Layanan Kesehatan Susu Untuk Ibu Hamil Kekurangan Energi Kronik 
INVENTORY : Jurnal Akuntansi Vol. 4 No. 1 April 2020

\begin{tabular}{|c|c|c|c|c|c|c|c|}
\hline \multirow[b]{2}{*}{ No } & \multirow[b]{2}{*}{ Uraian } & \multicolumn{4}{|c|}{ Rincian Perhitungan } & \multirow{2}{*}{\multicolumn{2}{|c|}{$\begin{array}{c}\text { Jumlah } \\
\text { Rp }\end{array}$}} \\
\hline & & Volume & Satuan & & arga Satuan & & \\
\hline 1 & 2 & 3 & 4 & & 5 & & $6=(3 * 5)$ \\
\hline \multirow[t]{4}{*}{1} & Belanja Barang Dan Jasa & & & & & & \\
\hline & * Honor Pengelola Kegiatan & 1 & Op & $\mathrm{Rp}$ & $200,000.00$ & $\mathrm{Rp}$ & $200,000.00$ \\
\hline & * Transport Kegiatan & 12 & Pjl & $\mathrm{Rp}$ & $50,000.00$ & $\mathrm{Rp}$ & $600,000.00$ \\
\hline & $\begin{array}{l}* \text { Susu Untuk Ibu Hamil } 5 \times \\
12 \times 2\end{array}$ & 120 & Duz & $\mathrm{Rp}$ & $90,000.00$ & $\mathrm{Rp}$ & $10,800,000.00$ \\
\hline \multicolumn{6}{|c|}{ Jumlah } & $\mathrm{Rp}$ & $11,600,000.00$ \\
\hline
\end{tabular}

Tabel 4.11 menunjukkan perincian anggaran layanan kesehatan susu bagi ibu hamil kekurangan energi kronik, sama seperti 2 program sebelumnya TPK juga bekerja sama dengan kader posyandu dalam penanganan kesehatan ibu hamil yang mengalami kekurangan energi kronik artinya kader posyandu bertugas menyampaikan data ibu hamil yang mengalami kekurangan energi kronik dan terus memantau perkembangan ibu hamil selama proses penanganan layanan kesehatan susu tetap berlangsung.

Dalam perinciannya ada 5 ibu hamil yang dianggarkan menerima layanan susu sebanyak 2 duz per bulan selama 12 bulan, namun dalam pelaksanaannya bersifat fleksibel artinya penerima manfaat layanan susu sebelumnya akan diganti dengan penerima manfaat yang baru ketika ibu hamil yang sedang menerima layanan susu telah bersalin.

Selain anggaran disediakan untuk membeli susu anggaran juga disediakan bagi pengelola kegiatan berupa honor sebesar Rp.200.000/tahun anggaran 2017 dan biaya transport selama 12x pengelola kegiatan mengakomodasi layanan susu bagi setiap ibu hamil sebesar Rp. 50.000/bulan.

Sehingga total dana yang digunakan dalam pengelolaan kegiatan layanan susu bagi ibu hamil kekurangan energi kronik adalah sebesar Rp. 11.600.000,00dan program ini telah terealisasi dengan baik selama tahun anggaran 2017.

Layanan Pendidikan Transport Siswa Anak Penyandang Cacat Vol 3 Orang Tabel 4.12 Rincian Perhitungan Anggaran Layanan Pendidikan Transport Siswa Anak Penyandang Cacat Vol 3 Orang

\begin{tabular}{|c|c|c|c|c|c|c|}
\hline \multirow[b]{2}{*}{ No } & \multirow{2}{*}{ Uraian } & \multicolumn{4}{|c|}{ Rincian Perhitungan } & Jumlah \\
\hline & & Volume & Satuan & Har & Satuan & $\mathrm{Rp}$ \\
\hline 1 & 2 & 3 & 4 & & 5 & $6=(3 * 5)$ \\
\hline 1 & Belanja barang dan jasa & & & & & \\
\hline & * Transprot siswa ABK $3 \times 12$ & 36 & bulan & $\mathrm{Rp}$ & $20,000.00$ & $\mathrm{Rp} \quad 18,720,000.00$ \\
\hline
\end{tabular}

Tabel 4.12 menunjukkan bahwa di Desa Amahai ada 3 anak berkebutuhan khusus (cacat) yang transport sekolahnya dibiayai oleh Pemerintah Negeri Amahai. Ini sangat mempermudah para orang tua dikarenakan biaya sekolah yang mahal dan letak sekolah yang cukup jauh sehingga 3 orang anak ini tidak dapat menempuh pendidikan dengan baik sehingga Pemerintah Negeri Amahai mempermudahnya dengan memberikan uang transport sehingga setiap harinya mereka dapat pergi ke sekolah. 
Biaya transport dalam rincian perhitungan diatas dapat dijelaskan bahwa setiap siswa selama 12 bulan menerima ongkos angkutan sebesar Rp. 20.000/hari sehingga dalam tahun anggaran 2017 total biaya transport bagi siswa Anak berkebutuhan khusus adalah sebesar Rp. 18.720.000.00,- .

Ini menunjukkan bahwa Program layanan pendidikan transport siswa ABK ini terelisasi dengan baik dari tahun 2017 meski pada tahun anggaran terjadi keterlambatan pencairan Dana Desa dan program ini masih terus dianggarkan dalam APBNeg tahun 2018 dan tahun 2019.

Bantuan Insentif Kader Posyandu/ GSC

Tabel 4.13 Rincian Perhitungan Anggaran Bantuan Insentif Kader Posyandu/ GSC

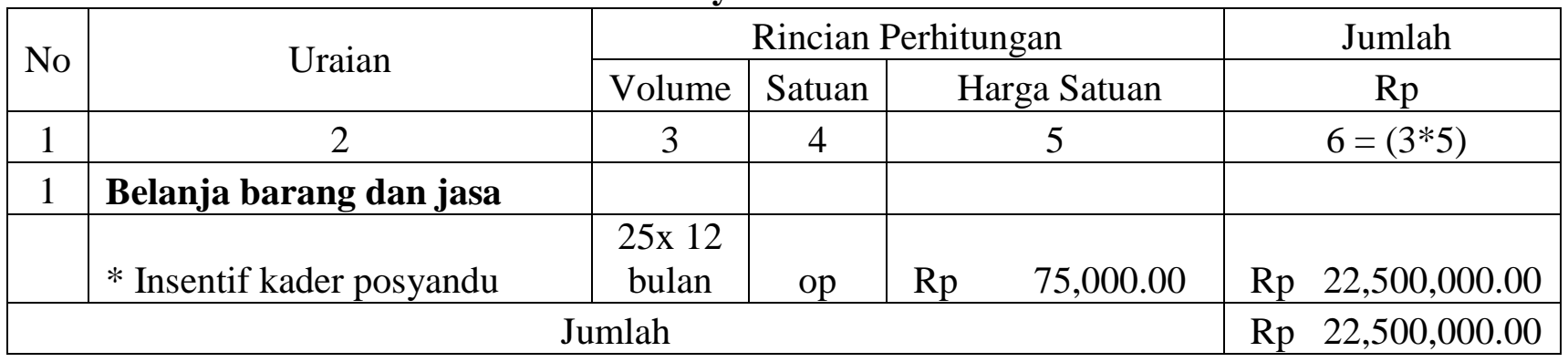

Tabel 4.13 menunjukan rincian anggaran program insentif kader posyandu selama 1 tahun angagaran. Insentif kader posyandu ini diberikan oleh pemerintah negeri amahai sebagai balas jasa atas kerja sama kader posyandu dengan Pemerintah Negeri Amahai lewat program penanganan PMT bayi dan balita, penanganan bayi dan balita gizi buruk dan layanan kesehatan susu bagi ibu hamil kekurangan energi kronik dan juga untuk menunjang kualitas pelayanan kader posyandu dalam pelayanan kesehatan masyarakat bersama pihak Puskesmas. Dalam perinciannya kader posyandu berjumlah 25 orang mendapatkan insentif sebesar Rp. 75.000/bulan sehingga dalam 1 tahun anggaran 2017 total anggaran insentif kader posyandu yang diberikan oleh Pemerintah Negeri Amahai adalah sebesar Rp. 22.500.000.00

Pengadaan Sarana Prasarana Kesehatan Dan Obat Poskes Negeri

Tabel 4.14 Rincian Perhitungan Anggaran Pengadaan Sarana Prasarana Kesehatan Dan Obat Poskes Negeri

\begin{tabular}{|c|c|c|c|c|c|c|c|}
\hline \multirow{2}{*}{ No } & \multirow{2}{*}{ Uraian } & \multicolumn{4}{|c|}{ Rincian perhitungan } & \multirow{2}{*}{\multicolumn{2}{|c|}{$\begin{array}{c}\text { Jumlah } \\
\text { Rp }\end{array}$}} \\
\hline & & Volume & Satuan & & arga Satuan & & \\
\hline 1 & 2 & 3 & 4 & & 5 & & $6=(3 * 5)$ \\
\hline 1 & Belanja barang dan jasa & & & & & $\mathrm{Rp}$ & $2,450,000.00$ \\
\hline & * Honor pengelola kegiatan & 1 & op & $\mathrm{Rp}$ & $200,000.00$ & $\mathrm{Rp}$ & $200,000.00$ \\
\hline & $*$ Amoxilin $500 \mathrm{mg}$ & 5 & box & $\mathrm{Rp}$ & $70,000.00$ & $\mathrm{Rp}$ & $350,000.00$ \\
\hline & * Paracitamol $500 \mathrm{mg}$ & 1 & btl & $\mathrm{Rp}$ & $200,000.00$ & $\mathrm{Rp}$ & $200,000.00$ \\
\hline & * Antalagin $500 \mathrm{mg}$ & 2 & btl & $\mathrm{Rp}$ & $250,000.00$ & $\mathrm{Rp}$ & $500,000.00$ \\
\hline & * CTM $4 \mathrm{mg}$ & 1 & btl & $\mathrm{Rp}$ & $50,000.00$ & $\mathrm{Rp}$ & $50,000.00$ \\
\hline & $* \mathrm{GG}$ & 1 & btl & $\mathrm{Rp}$ & $50,000.00$ & $\mathrm{Rp}$ & $50,000.00$ \\
\hline & * Antasida doen & 1 & btl & $\mathrm{Rp}$ & $250,000.00$ & $\mathrm{Rp}$ & $250,000.00$ \\
\hline & * Asamafenamat $500 \mathrm{mg}$ & 1 & box & $\mathrm{Rp}$ & $30,000.00$ & $\mathrm{Rp}$ & $30,000.00$ \\
\hline
\end{tabular}


INVENTORY : Jurnal Akuntansi Vol. 4 No. 1 April 2020

\begin{tabular}{|c|c|c|c|c|c|c|c|}
\hline & * Ibuprovin & 1 & box & $\mathrm{Rp}$ & $30,000.00$ & $\mathrm{Rp}$ & $30,000.00$ \\
\hline & * Vitamin B 12 & 1 & btl & $\mathrm{Rp}$ & $30,000.00$ & $\mathrm{Rp}$ & $30,000.00$ \\
\hline & $*$ Vitamin B 1 & 1 & btl & $\mathrm{Rp}$ & $60,000.00$ & $\mathrm{Rp}$ & $60,000.00$ \\
\hline & * Dexametasone $0.5 \mathrm{mg}$ & 1 & btl & $\mathrm{Rp}$ & $50,000.00$ & $\mathrm{Rp}$ & $50,000.00$ \\
\hline & * Chlorampenicol & 2 & box & $\mathrm{Rp}$ & $45,000.00$ & $\mathrm{Rp}$ & $90,000.00$ \\
\hline & $*$ Cotrimoxazole & 1 & box & $\mathrm{Rp}$ & $45,000.00$ & $\mathrm{Rp}$ & $45,000.00$ \\
\hline & * Salbutamol & 1 & box & $\mathrm{Rp}$ & $30,000.00$ & $\mathrm{Rp}$ & $30,000.00$ \\
\hline & * Captropil & 1 & box & $\mathrm{Rp}$ & $25,000.00$ & $\mathrm{Rp}$ & $25,000.00$ \\
\hline & $*$ Nifedin & 1 & box & $\mathrm{Rp}$ & $25,000.00$ & $\mathrm{Rp}$ & $25,000.00$ \\
\hline & * Disposibel $3 \mathrm{cc}$ & 1 & dos & $\mathrm{Rp}$ & $250,000.00$ & $\mathrm{Rp}$ & $250,000.00$ \\
\hline & $*$ Alkohol 70\% & 1 & ltr & $\mathrm{Rp}$ & $35,000.00$ & $\mathrm{Rp}$ & $35,000.00$ \\
\hline & * Plester rol & 1 & rol & $\mathrm{Rp}$ & $25,000.00$ & $\mathrm{Rp}$ & $25,000.00$ \\
\hline & * Betadin $100 \mathrm{cc}$ & 1 & botol & $\mathrm{Rp}$ & $60,000.00$ & $\mathrm{Rp}$ & $60,000.00$ \\
\hline & * Ambroxsol & 2 & box & $\mathrm{Rp}$ & $60,000.00$ & $\mathrm{Rp}$ & $120,000.00$ \\
\hline 2 & Belanja Modal & & & & & $\mathrm{Rp}$ & $3,213,000.00$ \\
\hline & * Tensimeter Manual & 1 & bh & $\mathrm{Rp}$ & $200,000.00$ & $\mathrm{Rp}$ & $200,000.00$ \\
\hline & * Stetoscope & 1 & bh & $\mathrm{Rp}$ & $236,000.00$ & $\mathrm{Rp}$ & $236,000.00$ \\
\hline & $*$ Minor set & 1 & set & $\mathrm{Rp}$ & $300,000.00$ & $\mathrm{Rp}$ & $300,000.00$ \\
\hline & * Timbangan & 1 & $\mathrm{bh}$ & $\mathrm{Rp}$ & $177,000.00$ & $\mathrm{Rp}$ & $177,000.00$ \\
\hline & * Alat cek gds & 1 & set & $\mathrm{Rp}$ & $900,000.00$ & $\mathrm{Rp}$ & $900,000.00$ \\
\hline & * Stik cek gula darah & 1 & dos & $\mathrm{Rp}$ & $150,000.00$ & $\mathrm{Rp}$ & $150,000.00$ \\
\hline & * Stik cek asam urat & 1 & dos & $\mathrm{Rp}$ & $150,000.00$ & $\mathrm{Rp}$ & $150,000.00$ \\
\hline & * Stik cek kolestrol & 2 & dos & $\mathrm{Rp}$ & $300,000.00$ & $\mathrm{Rp}$ & $600,000.00$ \\
\hline & $\begin{array}{l}\text { * Termometer digital anak / } \\
\text { dewasa }\end{array}$ & 2 & bh & $\mathrm{Rp}$ & $250,000.00$ & $\mathrm{Rp}$ & $500,000.00$ \\
\hline \multicolumn{6}{|c|}{ Jumlah } & $\mathrm{Rp}$ & $5,663,000.00$ \\
\hline
\end{tabular}

Tabel 4.14 menunjukkan rincian anggaran dari program sarana prasarana kesehatan dan obat yang disediakan di Poskes Negeri. Poskes negeri ini menyediakan obat-obatan dan sarana prasarana kesehatan lainnya bagi masyarakat secara gratis. Poskes terletak di lingkungan Kupapuyoni mengingat letak lingkungan ini jauh dari pusat desa namun masih berada pada wilayah petuanan Negeri Amahai dan dapat dikatakan jauh dari akses kesehatan desa setempat maka Pemerintah Negeri Amahai berinisiatif menyediakan poskes pada lingkungan kupapuyoni. Program ini telah terealisasi dengan baik sehingga sejak tahun 2017 hingga sekarang masyarakat lingkungan Kupapuyoni dapat dengan mudah memperolah akses kesehatan kapan saja mereka perlukan.

Bantuan Asuransi Kesehatan BPJS Bagi Masyarakat Tidak Mampu

Tabel 4.15 Rincian Perhitungan Anggaran Bantuan Asuransi Kesehatan BPJS Bagi Masyarakat Tidak Mampu

\begin{tabular}{|c|c|c|c|c|c|}
\hline \multirow{2}{*}{ No } & \multirow{2}{*}{ Uraian } & \multicolumn{3}{|c|}{ Rincian perhitungan } & Jumlah \\
\cline { 2 - 6 } & & Volume & satuan & Harga Satuan & Rp \\
\hline 1 & 2 & 3 & 4 & 5 & $6=(3 * 5)$ \\
\hline
\end{tabular}


INVENTORY : Jurnal Akuntansi Vol. 4 No. 1 April 2020

\begin{tabular}{|c|c|c|c|c|c|c|}
\hline 1 & Belanja barang dan jasa & & & & & \\
\hline & $\begin{array}{l}\text { * Angsuran BPJS } 128 \text { org } \mathrm{x} \\
12 \text { bln }\end{array}$ & 1536 & angsuran & $\mathrm{Rp}$ & $23,000.00$ & $\mathrm{Rp} \quad 35,328,000.00$ \\
\hline \multicolumn{6}{|c|}{ jumlah } & $\operatorname{Rp} \quad 35,328,000.00$ \\
\hline
\end{tabular}

Tabel 4.15 menunjukkan rincian anggaran program Angsuran BPJS bagi 128 orang dari keluarga miskin sebesar Rp. 23.000/bulan selama 12 bulan (1 tahun anggaran) maka total anggaran yang disediakan oleh Pemerintah Negeri Amahai adalah berjumlah Rp 35.328.000-,

Berdasarkan hasil konfirmasi dengan penerima manfaat, program ini tidak terealisasi dan setelah di konfirmasi kembali dengan pemerintah negeri hal ini dikarenakan adanya kesalahan regulasi pada pemerintah kabupaten Maluku tengah bahwa anggaran yang digunakan untuk membiayai angguran BPJS adalah dana yang bersumber dari Alokasi Dana Desa (ADD) bukan menggunakan dana yang bersumber dari Dana Desa (DD) sehingga dananya tidak dicairkan dan dijadikan Silpa Tahun anggaran 2017 yang akan dibelanjakan untuk program lain di Tahun Anggaran 2018.

Bedah Rumah Tidak Layak Huni 4 Unit

Tabel 4.16 Rincian Anggaran Perhitungan Bedah Rumah Tidak Layak Huni 4 Unit

\begin{tabular}{|c|c|c|c|c|c|c|c|}
\hline \multirow[b]{2}{*}{ No } & \multirow{2}{*}{ Uraian } & \multicolumn{4}{|c|}{ Rincian perhitungan } & \multirow{2}{*}{\multicolumn{2}{|c|}{$\begin{array}{c}\text { Jumlah } \\
\text { Rp }\end{array}$}} \\
\hline & & Volume & satuan & & Iarga Satuan & & \\
\hline 1 & 2 & 3 & 4 & & 5 & & $6=(3 * 5)$ \\
\hline \multirow[t]{2}{*}{1} & Belanja barang dan jasa & & & & & $\mathrm{Rp}$ & $200,000.00$ \\
\hline & * Honor pengelola kegiatan & 1 & op & $\mathrm{Rp}$ & $200,000.00$ & $\mathrm{Rp}$ & $200,000.00$ \\
\hline \multirow[t]{9}{*}{2} & Belanja modal & & & & & $\mathrm{Rp}$ & $39,800,000.00$ \\
\hline & * Pasir 4x 3 M3 & 12 & $\mathrm{~m} 3$ & $\mathrm{Rp}$ & $200,000.00$ & $\mathrm{Rp}$ & $2,400,000.00$ \\
\hline & * Kerikil 4 X 3 M3 & 12 & $\mathrm{~m} 3$ & $\mathrm{Rp}$ & $200,000.00$ & $\mathrm{Rp}$ & $2,400,000.00$ \\
\hline & * Semen 4 X 17 Sak & 68 & sak & $\mathrm{Rp}$ & $83,000.00$ & $\mathrm{Rp}$ & $5,976,000.00$ \\
\hline & * Senk Gelombang 4x 50 Lbr & 200 & lbr & $\mathrm{Rp}$ & $58,000.00$ & $\mathrm{Rp}$ & $11,600,000.00$ \\
\hline & * Senk Licin 4 X $8 \mathrm{M}$ & 32 & $\mathrm{~m}$ & $\mathrm{Rp}$ & $15,000.00$ & $\mathrm{Rp}$ & $480,000.00$ \\
\hline & $\begin{array}{l}\text { * Papan Kls II 3cm } 4 \text { X 1,5 } \\
\text { M3 }\end{array}$ & 6 & $\mathrm{~m} 3$ & $\mathrm{Rp}$ & $2,764,000.00$ & $\mathrm{Rp}$ & $16,584,000.00$ \\
\hline & * Paku 7cm 4 X 2 Kg & 8 & $\mathrm{~kg}$ & $\mathrm{Rp}$ & $22,500.00$ & $\mathrm{Rp}$ & $180,000.00$ \\
\hline & * Paku $5 \mathrm{Cm} 4$ X $2 \mathrm{Kg}$ & 8 & $\mathrm{~kg}$ & $\mathrm{Rp}$ & $22,500.00$ & $\mathrm{Rp}$ & $180,000.00$ \\
\hline \multicolumn{6}{|c|}{ Jumlah } & $\mathrm{Rp}$ & $40,000,000.00$ \\
\hline
\end{tabular}

Tabel 4.16 menunjukan rincian anggaran program bedah rumah tidak layak huni sebanyak 4 unit yang terdiri dari honor pengelola kegiatan adalah sebesar Rp.200.000 dan belanja modal yang terdiri dari alat dan bahan bedah rumah sebesar Rp. 39.800.000,00. Bedah rumah tidak layak huni ini bervolume 4 unit yaitu 1 rumah yang terletak di lingkungan Alariano, 1 rumah di lingkungan Namano dan 2 rumah di lingkungan Ehumarna.

\section{Pembuatan Kebun Percontohan PKK 1500 m² $^{2}$}


INVENTORY : Jurnal Akuntansi Vol. 4 No. 1 April 2020

Tabel 4.17 Rincian Perhitungan Anggaran Pembuatan Kebun Percontohan

PKK 1500m²

\begin{tabular}{|c|c|c|c|c|c|c|c|}
\hline \multirow[b]{2}{*}{ No } & \multirow{2}{*}{ Uraian } & \multicolumn{4}{|c|}{ Rincian perhitungan } & \multirow{2}{*}{\multicolumn{2}{|c|}{$\begin{array}{c}\text { Jumlah } \\
\mathrm{Rp}\end{array}$}} \\
\hline & & Volume & satuan & & Iarga Satuan & & \\
\hline 1 & 2 & 3 & 4 & & 5 & & $6=(3 * 5)$ \\
\hline \multirow[t]{6}{*}{1} & Belanja barang dan jasa & & & & & $\mathrm{Rp}$ & $7,800,000.00$ \\
\hline & * Honor pengelola kegiatan & 1 & op & $\mathrm{Rp}$ & $200,000.00$ & $\mathrm{Rp}$ & $200,000.00$ \\
\hline & $\begin{array}{l}* \text { Upah untuk semai } \\
\text { pembibitan }\end{array}$ & 5 & op & $\mathrm{Rp}$ & $200,000.00$ & $\mathrm{Rp}$ & $1,000,000.00$ \\
\hline & * Upah Pembuatan Pagar & 4 & op & $\mathrm{Rp}$ & $250,000.00$ & $\mathrm{Rp}$ & $1,000,000.00$ \\
\hline & * Upah Pembuatan kebun & 2 & op & $\mathrm{Rp}$ & $300,000.00$ & $\mathrm{Rp}$ & $600,000.00$ \\
\hline & $\begin{array}{l}* \text { Sewa trector untuk area } \\
\text { kebun }\end{array}$ & 1 & unit & $\mathrm{Rp}$ & $5,000,000.00$ & $\mathrm{Rp}$ & $5,000,000.00$ \\
\hline \multirow[t]{12}{*}{2} & Belanja Modal & & & & & $\mathrm{Rp}$ & $11,270,000.00$ \\
\hline & $*$ Hiter & 1 & bh & $\mathrm{Rp}$ & $60,000.00$ & $\mathrm{Rp}$ & $60,000.00$ \\
\hline & * Speyer & 1 & bh & $\mathrm{Rp}$ & $120,000.00$ & $\mathrm{Rp}$ & $120,000.00$ \\
\hline & * Jaring Paranet & 1 & ball & $\mathrm{Rp}$ & $1,700,000.00$ & $\mathrm{Rp}$ & $1,700,000.00$ \\
\hline & * Polobek $15 \times 20 \mathrm{~cm}$ & 1 & ball & $\mathrm{Rp}$ & $250,000.00$ & $\mathrm{Rp}$ & $250,000.00$ \\
\hline & * Slank air $100 \mathrm{~m}$ & 1 & bh & $\mathrm{Rp}$ & $250,000.00$ & $\mathrm{Rp}$ & $250,000.00$ \\
\hline & * Tanah humus & 3 & $\mathrm{~m} 3$ & $\mathrm{Rp}$ & $200,000.00$ & $\mathrm{Rp}$ & $600,000.00$ \\
\hline & * Pasir kali & 1,5 & $\mathrm{~m} 3$ & $\mathrm{Rp}$ & $200,000.00$ & $\mathrm{Rp}$ & $300,000.00$ \\
\hline & * Bibit sayur 9 jenis $\mathrm{x} 4$ set & 36 & sachet & $\mathrm{Rp}$ & $45,000.00$ & $\mathrm{Rp}$ & $1,620,000.00$ \\
\hline & * Papan $2 \mathrm{~cm}$ ( tempat semai) & 6 & ptng & $\mathrm{Rp}$ & $45,000.00$ & $\mathrm{Rp}$ & $270,000.00$ \\
\hline & $*$ Bambu & 300 & bh & $\mathrm{Rp}$ & $15,000.00$ & $\mathrm{Rp}$ & $4,500,000.00$ \\
\hline & * Kayu buah & 160 & bh & $\mathrm{Rp}$ & $10,000.00$ & $\mathrm{Rp}$ & $1,600,000.00$ \\
\hline \multicolumn{6}{|c|}{ Jumlah } & $\mathrm{Rp}$ & $19,070,000.00$ \\
\hline
\end{tabular}

Kebun percontohan PPK dibuat dengan tujuan mengajak kaum perempuan untuk memanfaatkan waktu dan tenaga untuk bercocok tanam di pekarangan rumahnya masing-masing. Lahan pekarangan rumah dapat digunakan untuk menanam sayur mayur dan berbagai jenis tanaman bernilai ekonomi, secara tidak langsung program ini juga berkorelasi pada upaya peningkatan derajat kesehatan masyarakat artinya selain dimanfaatkan untuk penanaman sayur mayur juga dapat dimanfaatkan untuk menanam tanaman obat tradisonal sehingga masyarakat tidak cenderung bergantung pada obat-obatan yang berbahan kimia.

Tabel 4.17 menunjukkan rincian anggaran program pembuatan kebun percontohan PKK. Anggaran yang digunakan dalam kebun percontohan PKK terdiri dari belanja barang dan jasa sebesar Rp. 7.800.000 dan belanja modal sebesar Rp. 11.270.000 jadi total biaya yang terealisasi untuk program pembuatan kebun percontohan PKK adalah sebesar Rp. 19.070.000.00-,

\section{Pengadaan Alat Konveksi}

Tabel 4.18 Rincian Perhitungan Anggaran Pengadaan Alat Konveksi

\begin{tabular}{|l|l|l|l|}
\hline No & Uraian & Rincian perhitungan & Jumlah \\
\hline
\end{tabular}


INVENTORY : Jurnal Akuntansi Vol. 4 No. 1 April 2020

\begin{tabular}{|c|c|c|c|c|c|c|c|}
\hline & & Volume & Satuan & & Iarga Satuan & & $\mathrm{Rp}$ \\
\hline 1 & 2 & 3 & 4 & & 5 & & $6=(3 * 5)$ \\
\hline 1 & Belanja barang dan jasa & & & & & $\mathrm{Rp}$ & $200,000.00$ \\
\hline & * Honor pengelola kegiatan & 1 & $\mathrm{Op}$ & $\mathrm{Rp}$ & $200,000.00$ & $\mathrm{Rp}$ & $200,000.00$ \\
\hline 2 & Belanja Modal & & & & & $\mathrm{Rp}$ & $11,600,000.00$ \\
\hline & * Pengadaan mesin jahit & 2 & bh & $\mathrm{Rp}$ & $2,000,000.00$ & $\mathrm{Rp}$ & $4,000,000.00$ \\
\hline & * Pengadaan Mesin Obras & 2 & bh & $\mathrm{Rp}$ & $3,800,000.00$ & $\mathrm{Rp}$ & $7,600,000.00$ \\
\hline \multicolumn{6}{|c|}{ Jumlah } & $\mathrm{Rp}$ & $11,800,000.00$ \\
\hline
\end{tabular}

Tabel 4.18 menunjukkan rincian anggaran program Pengadaan Alat konveksi berupa mesin jahit dan mesin obras sebanyak 2 buah dengan rincian anggaran berupa honor pengelola kegiatan sebesar Rp. 200.000 dan belanja modal sebesar Rp. 11.600.000 total biaya yang teralisasi adalah Rp. 11.800.000-, Mesin jahit dan mesin obras ini diberikan kepada 2 orang penjahit pakaian masing-masing berdomisili di lingkungan Namano dan Hatusuiro. Pengadaan alat konveksi ini dilaksanakan dengan tujuan meningkatkan kemandirian ekonomi masyarakat terutama pada produktivitas dan pendapatan ekonomi mereka sehari-hari.

Program ini telah terealisasi meski dalam pengadaannya mengalami sedikit keterlambatan dimana mesin konveksi ini baru dibelanjakan dan diserahkan oleh TPK kepada penerima manfaat pada awal tahun 2018 namun pada dasarnya penerima manfaat akhirnya dapat memproduksi pakaian jahit berdasarkan permintaan pasar dan mampu meningkatkan pendapatan ekonomi mereka seharihari.

Pengadaan 1 unit Mesin Sablon Kaos Distro

Tabel 4.19 Rincian Perhitungan Anggaran Pengadaan 1 unit Mesin Sablon Kaos Distro

\begin{tabular}{|c|c|c|c|c|c|c|}
\hline \multirow[b]{2}{*}{ No } & \multirow[b]{2}{*}{ Uraian } & \multicolumn{3}{|c|}{ Rincian perhitungan } & \multirow{2}{*}{\multicolumn{2}{|c|}{$\begin{array}{c}\text { Jumlah } \\
\text { Rp }\end{array}$}} \\
\hline & & Volume & satuan & Harga Satuan & & \\
\hline 1 & 2 & 3 & 4 & 5 & & $6=(3 * 5)$ \\
\hline \multirow[t]{4}{*}{1} & Belanja Modal & & & & $\mathrm{Rp}$ & $24,800,000.00$ \\
\hline & * Printer DTG Epson 1390 & 1 & bh & $\operatorname{Rp} 15,000,000.00$ & $\mathrm{Rp}$ & $15,000,000.00$ \\
\hline & $*$ Heat Press $40 \times 60$ & 1 & $\mathrm{bh}$ & $\operatorname{Rp} 4,000,000.00$ & $\mathrm{Rp}$ & $4,000,000.00$ \\
\hline & $*$ Computer 1 unit & 1 & bh & $\operatorname{Rp} 5,800,000.00$ & $\mathrm{Rp}$ & $5,800,000.00$ \\
\hline \multicolumn{5}{|c|}{ Jumlah } & $\mathrm{Rp}$ & $24,800,000.00$ \\
\hline
\end{tabular}

Tabel 4.19 menunjukkan rincian anggaran program pengadaan 1 unit mesin sablon kaos distro dengan total biaya Rp. 24.800.000,00 dan mesin sablon distro ini diserahkan oleh Pemerintah Negeri Amahai kepada persatuan pemuda pemudi negeri amahai dengan tujuan mengurangi jumlah pengangguran dengan mendirikan komunitas usaha sablon bagi pemuda yang belum bekerja dan meningkatkan kreatifitas dalam membuat seni yang dituangkan dalam media kaos.

Setelah dikonfirmasi dengan Pemerintah Negeri Amahai pengadaan mesin sablon koas distro telah terealisasi tetapi belum digunakan dan diberdayakan oleh persatuan pemuda pemudi Negeri Amahai untuk menghasilkan produk barang. Kendalanya adalah dikarenakan belum adanya tenaga operasi penggunaan mesin sablon maka harus mengikuti pelatihan namun berkaitan dengan Persatuan pemuda pemudi di Desa Amahai yang saat itu mengalami kevakuman kepengurusan 
sehingga belum dapat menentukan siapa yang akan diakomodir untuk mengikuti pelatihan tersebut.

Pengadaan Etalase Makanan Siap Saji

Tabel 4.20 Rincian Anggaran Perhitungan Pengadaan Etalase Makanan Siap Saji

\begin{tabular}{|c|c|c|c|c|c|c|c|}
\hline \multirow[b]{2}{*}{ No } & \multirow[b]{2}{*}{ Uraian } & \multicolumn{4}{|c|}{ Rincian Perhitungan } & \multirow{2}{*}{\multicolumn{2}{|c|}{$\begin{array}{c}\text { Jumlah } \\
\mathrm{Rp}\end{array}$}} \\
\hline & & Volume & Satuan & & arga Satuan & & \\
\hline 1 & 2 & 3 & 4 & & 5 & & $6=(3 * 5)$ \\
\hline \multirow[t]{4}{*}{1} & Belanja Barang Dan Jasa & & & & & $\mathrm{Rp}$ & $1,150,000.00$ \\
\hline & * Honor Pengelola Kegiatan & 1 & Op & $\mathrm{Rp}$ & $200,000.00$ & $\mathrm{Rp}$ & $200,000.00$ \\
\hline & * Upah Kerja Buruh Bongkar Muat & 2 & Op & $\mathrm{Rp}$ & $200,000.00$ & $\mathrm{Rp}$ & $400,000.00$ \\
\hline & * Transport Untuk Distribusi Etalase & 1 & & $\mathrm{Rp}$ & $550,000.00$ & $\mathrm{Rp}$ & $550,000.00$ \\
\hline \multirow[t]{2}{*}{2} & Belanja Modal & & & & & $\mathrm{Rp}$ & $10,800,000.00$ \\
\hline & * Belanja Etalase Makanan Siap & 8 & Unit & $\mathrm{Rp}$ & $1,350,000.00$ & $\mathrm{Rp}$ & $10,800,000.00$ \\
\hline \multicolumn{6}{|c|}{ Jumlah } & $\mathrm{Rp}$ & $12,000,000.00$ \\
\hline
\end{tabular}

Tabel 4.20 menunjukkan rincian anggaran program pengadaan etalase makanan siap saji dengan total anggaran sebesar Rp. 12.000.000 yang terdiri dari belanja barang dan jasa sebesar Rp 1.150 .000 dan belanja modal sebesar Rp. 10.800.000-, Pengadaan Etalase makanan siap saji ini merupakan kelanjutan dari program bidang pembangunan Desa yaitu pembangunan pasar makanan siap saji desa sehingga setelah pasar rampung etalase ini juga disediakan.

Pasar Desa merupakan sarana yang disediakan oleh Pemerintah Negeri Amahai kepada masyarakat terkhususnya perempuan untuk berjualan makanan siap saji dan jajanan lainnya sehingga dengan adanya etalase makanan siap saji maka makanan yang dijual lebih higienis dan aman dikonsumsi dan juga memudahkan ibu-ibu penjual makanan untuk tidak lagi menjajahkan makanan di pinggir jalan, memperolah pendapatan untuk memenuhi kebutuhan keluarga serta mempermudah akses masyarakat untuk memperoleh bahan-bahan makanan yang akan dimasak atau makanan siap saji tanpa harus pergi ke pasar kota.

Pasar Desa dan program perlengkapan etalase makanan siap saji ini telah teralisasi dan terletak pada 4 lingkungan yaitu Lingkungan Namano, lingkungan Maruru, Lingkungan Siropu dan Lingkungan Hatusuiro.

\section{Kegiatan Musrenbang Negeri}

Tabel 4.21 Rincian Perhitungan Anggaran Kegiatan Musrenbang Negeri

\begin{tabular}{|c|c|c|c|c|c|c|c|}
\hline \multirow{3}{*}{$\begin{array}{c}\text { No } \\
1\end{array}$} & \multirow[b]{2}{*}{ Uraian } & \multicolumn{4}{|c|}{ Rincian perhitungan } & \multirow{2}{*}{\multicolumn{2}{|c|}{$\begin{array}{l}\text { Jumlah } \\
\text { Rp }\end{array}$}} \\
\hline & & Volume & Satuan & & rga Satuan & & \\
\hline & 2 & 3 & 4 & & 5 & & $6=(3 * 5)$ \\
\hline 1 & Belanja barang dan jasa & & & & & $\mathrm{Rp}$ & $15,472,000.00$ \\
\hline & * Honor Tim 5 org x 2 hari & 10 & op & $\mathrm{Rp}$ & $25,000.00$ & $\mathrm{Rp}$ & $250,000.00$ \\
\hline & * Transport Narasumber & 2 & op & $\mathrm{Rp}$ & $100,000.00$ & $\mathrm{Rp}$ & $200,000.00$ \\
\hline & * Honor Narasumber & 2 & op & $\mathrm{Rp}$ & $400,000.00$ & $\mathrm{Rp}$ & $800,000.00$ \\
\hline & * Kertas HVS & 2 & rim & $\mathrm{Rp}$ & $55,000.00$ & $\mathrm{Rp}$ & $110,000.00$ \\
\hline & $*$ Map & 85 & bh & $\mathrm{Rp}$ & $5,000.00$ & $\mathrm{Rp}$ & $425,000.00$ \\
\hline & * Notes & 85 & bh & $\mathrm{Rp}$ & $10,000.00$ & $\mathrm{Rp}$ & $850,000.00$ \\
\hline
\end{tabular}




\begin{tabular}{|c|c|c|c|c|c|c|}
\hline * Pulpen & 85 & bh & $\mathrm{Rp}$ & $5,000.00$ & $\mathrm{Rp}$ & $425,000.00$ \\
\hline * Cetak spanduk & 2 & bh & $\mathrm{Rp}$ & $150,000.00$ & $\mathrm{Rp}$ & $250,000.00$ \\
\hline * Fotocopy & 728 & lbr & $\mathrm{Rp}$ & 250.00 & $\mathrm{Rp}$ & $182,000.00$ \\
\hline * Dokumentasi / cetak Foto & 16 & lbr & $\mathrm{Rp}$ & $5,000.00$ & $\mathrm{Rp}$ & $80,000.00$ \\
\hline * Sewa Sound system & 2 & $\mathrm{hr}$ & $\mathrm{Rp}$ & $500,000.00$ & $\mathrm{Rp}$ & $1,000,000.00$ \\
\hline * Sewa Gedung & 2 & $\mathrm{hr}$ & $\mathrm{Rp}$ & $350,000.00$ & $\mathrm{Rp}$ & $700,000.00$ \\
\hline $\begin{array}{l}\text { * Snack } 85 \text { org x } 2 \text { hari } \\
* \text { Makan dan minum } 85 \text { org }\end{array}$ & 170 & org & $\mathrm{Rp}$ & $10,000.00$ & $\mathrm{Rp}$ & $1,700,000.00$ \\
\hline $\begin{array}{l}\text { x } 2 \text { hari } \\
\text { * Uang saku Peserta } 85 \text { org }\end{array}$ & 170 & org & $\mathrm{Rp}$ & $25,000.00$ & $\mathrm{Rp}$ & $4,250,000.00$ \\
\hline x 2 hari & $\begin{array}{c}170 \\
\text { Jumlah }\end{array}$ & org & $\mathrm{Rp}$ & $25,000.00$ & $\begin{array}{l}\mathrm{Rp} \\
\mathrm{Rp}\end{array}$ & $\begin{array}{r}4,250,000.00 \\
15,472,000.00\end{array}$ \\
\hline
\end{tabular}

Tabel 4.21 menunjukkan rincian anggaran kegiatan musrembang negeri Amahai dengan total biaya sebesar Rp. 15.472.000.00. Musrenbang yang didanai oleh Dana Desa tahun 2017 ini dilaksanakan pada awal tahun yaitu tanggal 7-8 Januari 2018.

\section{a. Penatausahaan}

Dalam proses pencairan Dana Desa melalui bendahara hingga sejumlah uang yang akan digunakan untuk membiayai kegiatan dan program pengelolaan dana desa haruslah melalui proses penatausahaan dengan memperhatikan buku bank, buku kas umum dan buku kas pembantu dll.

Proses penatausahaan itu antara lain penerimaan yang bersifat tunai yang diterima oleh Bendahara Desa dibuatkan bukti kuitansi tanda terima dan dicatat oleh Bendahara Desa pada Buku Kas Umum. Sedangkan untuk penerimaan yang bersifat transfer, Bendahara Desa akan mendapat informasi dari bank berupa Nota Kredit atas dana-dana yang masuk ke dalam Rekening Kas Desa. Berdasarkan nota kredit ini selanjutnya Bendahara Desa melakukan pencatatan ke dalam Buku Bank. Pencatatan penerimaan baik kas maupun transfer harus disertai dengan bukti yang lengkap dan sah serta dicatat secara benar dan tertib.

Hal ini juga berlaku bagi proses belanja artinya Belanja Kegiatan yang bersifat tunai yang dikeluarkan oleh Bendahara Desa dibuatkan bukti kuitansi pengeluaran dan dicatat oleh Bendahara Desa pada Buku Kas Umum. Sedangkan untuk Belanja yang bersifat transfer langsung ke pihak ketiga, Bendahara Desa melakukan pencatatan ke dalam Buku Bank (tidak dicatat di BKU, karena BKU untuk transaksi tunai).

Kemudian penatausahaan yang dilakukan oleh Pelaksana Kegiatan berupa pencatatan dalam Buku Kas Pembantu Kegiatan dan Laporan Kegiatan ketika kegiatan telah selesai. Buku Kas Pembantu Kegiatan mencatat penerimaan yang diperoleh dari Bendahara Desa (panjar) atau dari masyarakat (swadaya) yang telah dirupiahkan. Pengeluaran dicatat oleh Pelaksana Kegiatan atas belanja-belanja yang telah dilakukan baik berupa belanja barang/jasa maupun belanja modal.

\subsubsection{Keterlambatan Penyaluran Dana Desa}

Bidang pemberdayaan masyarakat tahun anggaran 2017 dalam pelaksanaannya terjadi kendala bukan hanya untuk bidang pemberdayaan masyarakat saja tetapi juga pada bidang penyelenggaraan pemerintah desa, bidang pembangunan desa dan bidang pembinaan masyarakat desa dikarenakan pada tahun 
2017 ini terjadi keterlambatan penyaluran Dana Desa yang alasannya sendiri tidak diketahui oleh pemerintah desa.

Dana Desa yang harusnya dicairkan pada bulan april tahun 2017 mengalami penundaan hingga bulan juni 2017. Dengan demikian seluruh pembangunan fisik dan pemberdayaan masyarakat yang telah direncanakan pada tahap pertama mengalami keterlambatan dalam proses realisasinya sehingga laporan realisasi tahap 1 belum dapat disampaikan hingga pada waktu pencairan Dana Desa tahap 2 pada bulan agustus, pencairan Dana Desa tahap 2 pun mengalami keterlambatan dari bulan agustus hingga bulan desember 2017.

Namun meski demikian Pemerintah Desa Amahai harus tetap mencari jalan keluar meski Dana Desa yang dicairkan terlambat tetapi kegiatan dan programprogram pengelolaan dana desa tetap terealisasikan mengingat ada program dan kegiatan yang bersifat multi yaitu harus berjalan setiap bulannya.

Yang dimaksudkan dengan berpegang pada mekanisme dan aturan yang disampaikan oleh pemerintah adalah bahwa Pemerintah Desa dalam hal ini PTPKD dan TPK dalam merealisasikan Dana Desa dalam waktu yang sempit haruslah tetap berdasarkan prosedur pengelolaan yang tepat meski waktu penyerapan dana sempit karena dana yang dicairkan terlambat namun dalam kurun waktu dekat harus kembali menyampaikan laporan realisasi penggunaan dana. Pemerintah Desa Amahai dalam hal ini PTPKD dan TPK mengambil inisiatif dengan menggunakan pinjaman pihak ketiga atau pengontrakan pada bidang pembangunan Desa tahun 2017.

Sedangkan dalam bidang pemberdayaan masyarakat dari 13 kegiatan secara keseluruhan direalisasikan ketika dana dicairkan karena dalam pelaksanaanya tidak terburu-buru dengan waktu seperti pada bidang pembangunan atau ada juga kegiatan yang dalam pelaksanaannya menggunakan sistem pinjaman pihak ketiga jadi ada pihak yang mau meminjamkan dana guna perealisasian kegiatan bidang pemberdayaan masyarakat dan dana tersebut akan digantikan pada saat dana desa telah dicairkan.

Hanya saja ada beberapa program yang bersifat multi artinya program tersebut harus dilaksanakan setiap bulannya dan tidak melalui sistem pinjaman pihak ketiga meski terjadi keterlambatan dana desa.

Program-program tersebut antara lain :

a. Program Layanan Pendidikan Transport Siswa Anak Berkebutuhan Khusus Volume 3 Orang.

b. Program Layanan Kesehatan Susu Untuk Ibu Hamil Kekurangan Energi Kronik

c. Program penanganan Anak dan Balita kurang gizi

Dilihat dari program dan kegiatan pelaksanaan pengelolaan dana desa yang tetap terealisasi meski dalam waktu penyerapan dana yang sempit pada desa amahai ketika terjadi keterlambatan penyaluran dana desa menunjukan bahwa TPK pada desa amahai memiliki kesiapan dalam meminimalisir akibat keterlambatan penyaluran dana desa terutama bidang pemberdayaan masyarakat.

Selain itu dalam proses penatausahaannya meski telah terjadi keterlambatan penyaluran dana desa namun telah tetap dikelola dengan baik oleh TPK melalui inisiatif-inisiatif yang digunakan sehingga dalam laporan realisasi pertanggungjawaban penggunaan dana desa tidak terlihat bahwa dalam pelaksanaan pengelolaan dana desa mengalami kendala dalam proses pencairan dana desa dan berdampak pada waktu penyerapan dana yang sempit. 


\section{KESIMPULAN}

Berdasarkan hasil penelitian dan pembahasan yang telah dilakukan mengenai pengelolaan Dana Desa dalam meningkatkan pembangunan Desa di Desa Amahai Kecamatan Amahai tahun 2017 dengan melihat perencanaan, pelaksanaan dan penatausahaan pada bidang pemberdayaan masyarakat maka peneliti menyimpulkan beberapa hal antara lain :a). Pengelolaan Dana Desa di Desa Amahai yang dimulai dari tahap perencanaan, pelaksanaan dan tahap penatausahaan telah dikatakan baik meski belum efektif. Hal ini dapat dibuktikan dengan penyusunan RPJM (Rencana Pembangunan Jangka Menengah) dan RKP Desa (Rencana kerja Pemerintah Desa) tepat waktu dan mengutamakan prioritas yang merupakan kebutuhan masyarakat, namun tidak seluruh program telah terelisasi sesuai dengan rencana kerja pemerintah desa yang telah ditetapkan. b).Berdasarkan daftar rencana kegiatan pemberdayaan masyarakat ada 13 kegiatan yang direncanakan dan dalam perealisasiannya 11 kegiatan dapat dilaksanakan. Tetapi ada 2 program yang tidak diadakan yaitu bantuan Asuransi kesehatan BPJS bagi masyarakat tidak mampu dikarenakan adanya perbedaan regulasi Pada Pemerintah Kabupaten Maluku Tengah dan Pengadaan 1 unit mesin sablon kaos distro yang telah terealisasi tetapi belum dimanfaatkan oleh penerima manfaat untuk menghasilkan produk dikarenakan adanya kevakuman kepemimpinan dalam persatuan pemuda pemudi negeri Amahai. c). Dari segi manfaat program pemberdayaan masyarakat untuk masyarakat desa sebagai penerima manfaat, masyarakat sangat merasa terbantu dengan adanya program-program pemberdayaan ini terbukti lewat hasil konfirmasi peneliti dengan penerima manfaat dan observasi selama penelitian. Masyarakat dapat dengan mudah memperoleh akses kesehatan dan pendidikan, berkurangnya angka anak dan balita kurang gizi dan meningkatnya pendapatan ekonomi masyarakat.

\section{DAFTAR PUSTAKA}

Aziz, Letty L N. 2016.Otonomi desa dan efektivitas dana desa. Jurnal Penelitian Politik Volume 13 No. 2

Bungin, Burhan. 2007. Analisis Data PenelitianKualitatif.Jakarta : PT Raja GrafindoPersada

Emzir. 2014. MetodologiPenelitianKualitatif: Analisis Data. Jakarta: RajawaliPers https://media.neliti.com/media/publications/75802-ID-pengelolaan-alokasi-danadesa-dalam-pemb.pdf

https://www.siswapedia.com/pengertian-dan-ciri-ciri-desa/

Kila, K Kristina. 2016. Pengelolaan Alokasi Dana Desa Dalam Meningkatkan Pemberdayaan Masyarakat Di Desa Miau Baru Kecamatan Kongbeng Kabupaten Kutai Timur.eJournal Administrasi Negara, Volume 5 , No 1

Miles danHuberman, 2010.TerampilMengelolah Data KualitatifDengan NVIVO.Penerbit :Prenada Media Group Jakarta

Moleong. J Lexy 1990. Metode Penelitian Kualitatif. Bandung : PT Remaja Rosdakarya.

PeraturanPemerintahDalamNegeriNomor 114 Tahun 2014 tentang Pedoman Pembangunan Desa

$\begin{array}{llll}\text { PeraturanPemerintahDalamNegeriNomor } & 113 & \text { Tahun } & 2014\end{array}$ tentangPengelolaanKeuanganDesa 
INVENTORY : Jurnal Akuntansi Vol. 4 No. 1 April 2020

Rosalinda, Okta. 2014. PengelolaanAlokasi Dana Desa (ADD) DalamMenunjang

Pembangunan PedesaanStudiKasusDesaSegodorejodanDesaPlosoKerep,

KecamatanSumobito, KabupatenJombang

Sarwono, Jonathan. 2006. Metode Penelitian Kuantitatif dan Kualitatif. Yogyakarta : Graha Ilmu

Sabarguna, Boy. 2005. Analisis data penelitian Kualitatif. Jakarta : Penerbit Universitas Indonesia.

Sutoro,E., Putra, A.S., Akhmadin, M., Suhirman.,Prayitno, H., Suryana, N., Mustakim, Z. 2016. Dana DesauntukDesaMembangun Indonesia: Tanya Jawabseputar Dana Desa, Jakarta :Kemendesa

Sugiyono.2003 .MetodePenelitianBisnis. EdisiKeTiga. Bandung: CV.Alfabeta

Undang-UndangNomor 6 Tahun 2014 tentangDesa

Zulganef. 2008. Metode Penelitian sosial dan bisnis. Edisi Pertama. Yogyakarta : Graha Ilmu. 
INVENTORY : Jurnal Akuntansi Vol. 4 No. 1 April 2020 